\title{
ANALYSIS OF MORPHOLOGICAL AND HYDROLOGICAL CHANGES IN THE CORRENTES RIVER
}

\author{
Edson Rodrigo dos Santos da SILVA ${ }^{1}$ \\ Aguinaldo SILVA ${ }^{1}$ \\ Beatriz Lima de Paula SILVA ${ }^{1}$ \\ Luciana Escalante PEREIRA ${ }^{1}$ \\ Edward L. LO2 \\ Tayrine Pinho de Lima FONSECA ${ }^{3}$ \\ Maxwell da Rosa OLIVEIRA ${ }^{1}$
}

\begin{abstract}
Meandering rivers have a number of features that differentiate them from rectilinear and anastomosing channels, such as the rapid change of course, which is the result of continuous adjustments of hydro-sedimentary factors. Studying these changes helps to inform on the potential future changes, and generates valuable data for landuse planning. This study aims to identify the morphological changes in the lower Correntes River between 1984 and 2016, and generate information that is currently scarce about the watershed. A temporal analysis of migrating meanders using remote sensing, literature search, and field work was conducted. This river is highly mobile with lateral and downstream migration, exhibiting a rectilinear channel tendency as shown by the decreased sinuosity between 1984 and 2016. This trend reflects channel adjustment in relation to hydro-sedimentary factors. Because the upstream hydroelectric dam retained sediment and enhanced flow velocity, erosion and meander migration increased. In addition to the channel modification, the dam caused observable changes to the river stage and discharge.
\end{abstract}

Key words: Geo-technology. Fluvial dynamics. Correntes River. Pantanal.

\footnotetext{
1 Laboratório de Estudos Socioambientais, Universidade Federal de Mato Grosso do Sul - Campus do Pantanal - Avenida Rio Branco, 1270 - CEP: 79.304-902 - Corumbá-MS. E-mails: edson_r_silva@yahoo.com; \{aguinald_silva, beatrizlpaula\}@yahoo.com.br; \{1.escalante.pereira, max.oliveira2102\} @gmail.com

2 Department of Earth and Environmental Sciences, University of Kentucky - UK. 101 Slone Research BIdg. Lexington, KY 40506-0053, USA. E-mail: edward.lo@uky.edu

3 Mestrado em Estudos Fronteiriços, Universidade Federal de Mato Grosso do Sul - UFMS-CPAN, Corumbá, MS, Brasil. E-mail: Tayrine.fonseca@hotmail.com
} 


\section{Resumo}

\section{Análise das mudanças morfológicas e hidrológicas no rio Correntes}

Os rios meandrantes apresentam uma série de características que os diferenciam dos canais retilíneos e anastomosados, como por exemplo, as rápidas mudanças de seu curso, resultado de ajustes contínuos dos fatores hidrossedimentológicos. O estudo dessas mudanças possibilita, dentre outros resultados, conceber conhecimento sobre possíveis mudanças futuras, gerando informações para o planejamento e ordenamento territorial. Neste sentido, o presente trabalho objetiva identificar as mudanças morfológicas ocorridas no baixo rio Correntes entre os anos de 1984 e 2016 , bem como gerar informações sobre sua bacia hidrográfica, atualmente escassas. Para tanto, fora utilizado sensoriamento remoto para análise temporal da migração dos meandros, pesquisa bibliográfica e trabalho de campo. O canal fluvial apresentou alta mobilidade, através da migração lateral e a jusante, exibindo uma tendência ao retilineamento do canal, constatada pela diminuição da sinuosidade entre 1984 e 2016. Essa tendência reflete o ajuste do canal em relação aos fatores hidrossedimentológicos, visto que a instalação de barramento para aproveitamento hidrelétrico a montante da região reteve sedimentos e potencializou a velocidade da corrente, aumentando a erosão e, consequentemente, a migração de meandros. Além da modificação do canal foi possível observar alteração na vazão e na cota do rio Correntes em decorrência do barramento.

Palavras-chave: Geotecnologias. Dinâmica fluvial. Rio Correntes. Pantanal.

\section{INTRODUCTION}

Fluvial channels are often described as rectilinear, anastomosed, or meandering. According to Leopold et al. (1957), rectilinear rivers are rare and located in short stretches of channels or in tectonic faults. In contrast, anastomosed systems are characterized by a significant bedload and river discharge that can form several channels which diverge and converge along the river channel.

According to Christofoletti (1981) the term 'meander' originates from the Maiandros River in Turkey. This term defines a type of river channel characterized by sinuous, wide uniform curves. It is an open system seeking a state of stability through continuous excavation in the concave margin and deposition in the convex margin (Langbein et al., 1966). Meandering rivers are common in humid and flat areas covered by riparian vegetation. For Guerra et al. (2009), a meandering channel can be differentiated from other channel patterns by the sinuosity index, which in this case must be $\geq 1.5$.

The dynamics of the meandering channels originate from lateral and downstream migration that can enlarge and renew the floodplain either by expanding the curves or by cutting meanders. However, the development of meanders depends on several factors, such as unconsolidated sedimentary layers, moderately low topographic gradients, continuous and regular flows, relatively equivalent bedload and suspended loads (ibid.).

In the meandering rivers, the development of fluvial system imprints marks on the surrounding plain. Meander scars, oxbow lakes, and other marks can cover a varied temporal and spatial scale (DEBOER, 1992). Studying the morphological transformations of the meandering channels and their forms allows understanding past processes and to think carefully about future changes. 
In the last few decades, important studies were carried out on meandering rivers in Brazil (Morais, 2002; Morais et al., 2006) and others focused on the Pantanal river systems (ASSINE et al. 2009; MACEDO et al. 2014; CORRADINI, 2011; SILVA, 2006; PUPIM, 2014; KUERTEN, 2010; MACEDO, 2013; SILVA, 2010; FERREIRA et al. 2012). These studies contribute to the identification of fluvial dynamics and the interpretation of the current landscapes.

However, according to Coelho et al. (2014), large interventions may interrupt the longitudinal balance of the river, forcing it to adjust and generate new modifications in the river channel. Hydroelectric dams considerably alter a river system. Several studies identified the effects of dams on river discharge, sediment transport, river geomorphology, riparian vegetation, traditional communities, and fish production (COELHO, 2008; SOUZA FILHO, 2013; GRAF, 2006; WILLIAMS et al. 1984; PETTS et al. 2005; GERMANOSKI, et al. 1988; GORDON et al. 2006; MENDES, 2005; MIRANDA, 2001).

The objective of this work was to identify the morphological changes occurring in the lower Correntes River between 1984 and 2016. Using remote sensing techniques and field survey, information was generated about the basin morphology, active processes, and the effect of the dam on the hydrological regime of the channel. Thus, identifying past changes, it is possible to interpret future changes and produce information for land-use planning and future research in fluvial geomorphology.

\section{MATERIAL AND METHODS}

According to SEMA (2005), the source of the Correntes River is located at an altitude of $750 \mathrm{~m}$ between both Serra da Saudade and Maracaju. It flows approximately $245 \mathrm{~km}$ to its mouth at the confluence with the Piquiri River, at an altitude of $154 \mathrm{~m}$. With an area of $\sim 5,410 \mathrm{~km}^{2}$, its hydrographic basin is divided between Mato Grosso (MT) with 2,131 $\mathrm{km}^{2}$ and Mato Grosso do Sul (MS) States with 3,279 km² (Figure 1). It includes four municipalities: Sonora and Pedro Gomes in MS, and Itiquira and Alto Araguaia in MT. However, only the city of Sonora with a population of 17,019 inhabitants is located in the basin (IBGE, 2014).

On the plateau, the Correntes River flows between rocks of Detrital-Lateritic cover, Holocene alluvium, and the Marília, Botucatu, and Furnas formations. Three geomorphological features are prominent: the Taquari-Itiquira plateau, the Chapadas and, in some sections, fluvial plains which widen to two kilometers. As for the soils, the Latosols and Neosols have textures varying between medium and sandy. There is a strong predominance of agricultural activities, predominating especially soybean, rice, corn, and sugarcane cultivation. The municipality of Sonora is one of the largest producers in the region.

At the highest point from the old axis of the Campo Grande-Cuiabá road, the Correntes River passes under the road through a natural tunnel approximately $300 \mathrm{~m}$ long. This karstic phenomenon known as 'Resurgence' occurs in rocks of the Furnas Formation, which noticeably consists of cross-stratified white and red sandstones. Melo et al. (2011), when studying the Campos Gerais in Paraná State, highlighted the characteristics of the Furnas Formation which form a Karst relief, mainly by dissolution and subsurface erosion of rocks. 


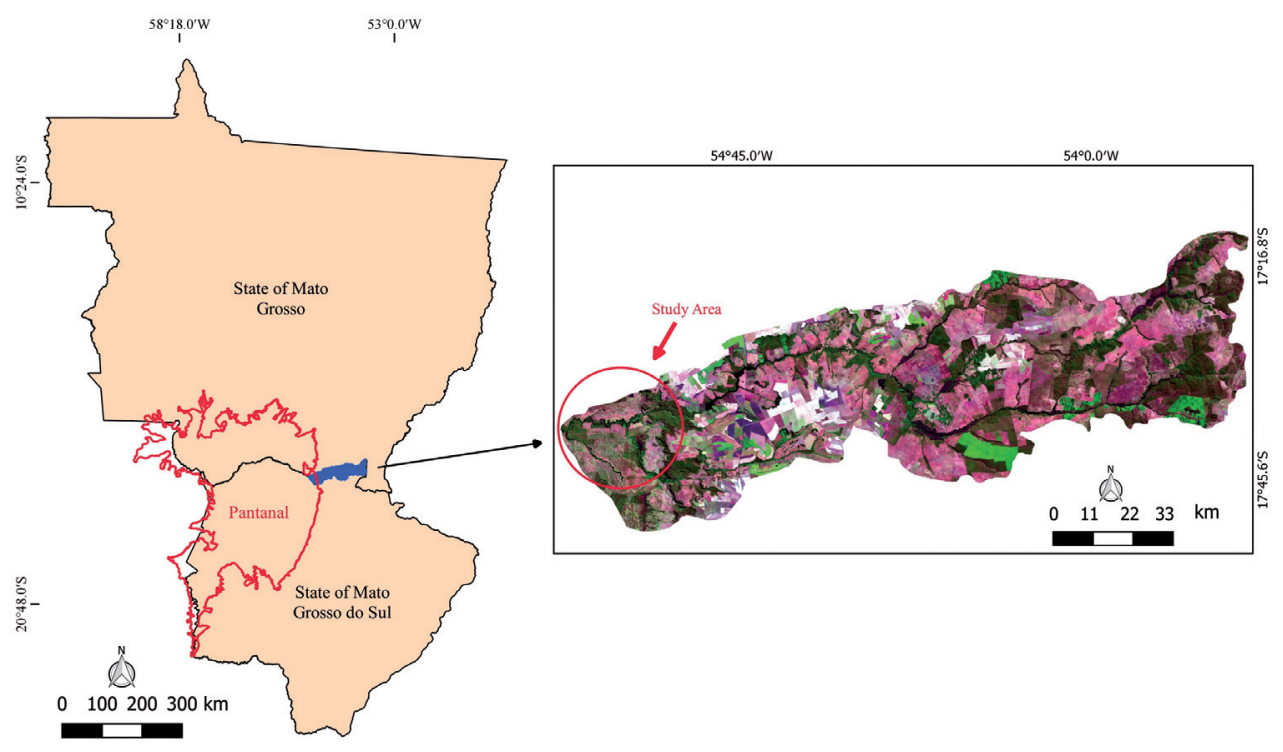
Figure 1 - Location Map of the Correntes River Basin.
The red circle highlights the area under study

From the point of view of energy production, those sites with the highest hydropower potential are located in the regions with the highest slopes (SOUZA FILHO, 2013). In the Upper Paraguay Basin, the steepest slopes are located on the plateau and at the plateau-floodplain transition. Thus, the Correntes River has been the target of several hydroelectric projects, with the installation of the small hydro-electric power plants (HPPs) Ponte de Pedra (176 MW), Aquárius (4.2 MW) and Santa Gabriela (24 MW). Additionally there are developments also exist in the available reach at Santa Paula (5.3 MW), Água Enterrada (14.5 MW), and Aquárius II (4.25 MW) (ANEEL, 2015). Ponte de Pedra has a dam of approximately $13.8 \mathrm{~km}^{2}$. Further downstream of all developments, Aquárius is located in the outskirts of an area with approximately 4,324 $\mathrm{km}^{2}$ of the Correntes River Basin (SOUZA FILHO, 2013).

Between the end of the karst tunnel and the beginning of the Pantanal plain, the Correntes River flows along a topographic gradient of $13 \mathrm{~m} / \mathrm{km}$ in a deep valley excavated in the Furnas Formation rocks. In this river section, the water gets speed, forming some rapids and waterfalls (SEMA, 2005). However, with the installation and operation of the Ponte de Pedra power plant, the flow in this section decreased to only the volume released by the spillways. The main volume is captured by the adduction channel (Figure 2), directed through the powerhouse, and released miles below, close to the Pantanal plain (Figure 3).

In the Pantanal, the Correntes River flows in a meandering belt, surrounded by a fluvial plain approximately $1.5 \mathrm{~km}$ wide. This plain is located on Holocene alluvium consisting predominantly of sandy, coherent, and consolidated sedimentary layers resulting from sedimentation in the river channel. In this plain, there are: riparian vegetation (in contrast to the surrounding pastures), abandoned meanders (meander scars), sedimentary bars (point bars) and meander lakes (oxbow lakes). 


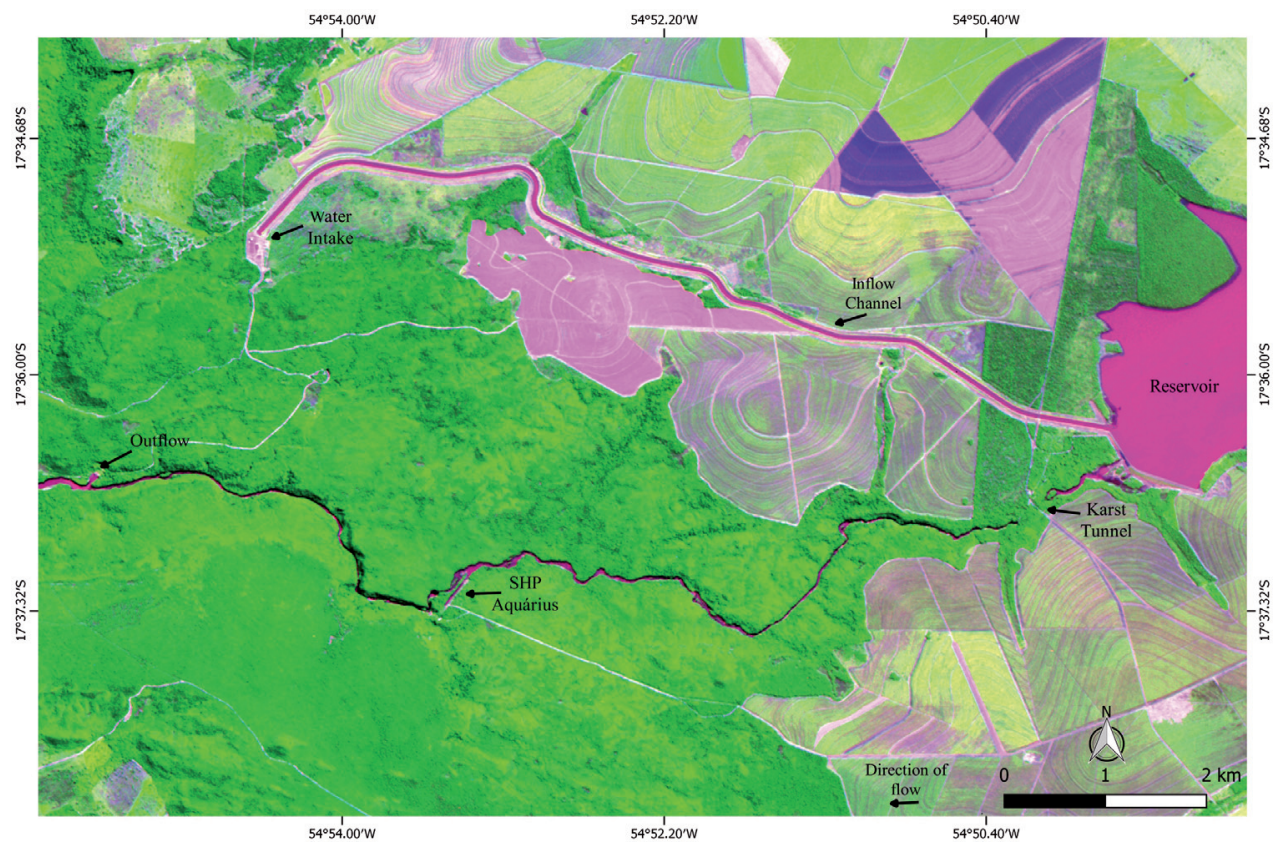

Figure 2 - Location of the Ponte de Pedra HPP and the natural channel of the Correntes River. In the image, the land use around the reservoir is visible

Source: CBERS 4, composition R2G4B3, May 2016.

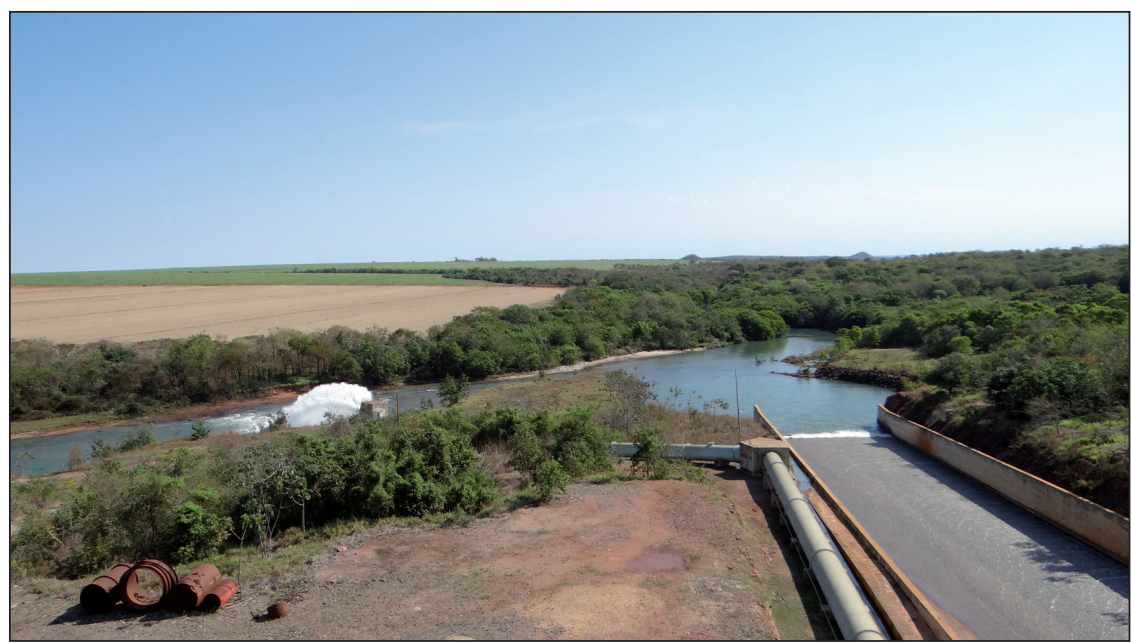

Figure 3 - Spillways of the Ponte de Pedra HPP and the natural channel of the Correntes River. In this section of $\sim 12.7 \mathrm{~km}$ length, the flow comes exclusively from water releases of $\geq 9.7 \mathrm{~m}^{3} / \mathrm{s}$ (August 2016) 
The morphological changes were identified between 1984 and 2016 using LANDSAT TM 5 (225/72) satellite images from September 1984 and the recently launched CBERS 4, (165/120), May 2016, a panchromatic camera with 10-m spatial resolution. The 225/72 scene of LANDSAT OLI 8 (2014) and SRTM 30-m resolution images were also used to produce the digital elevation model (DEM) of the Correntes River Basin. Geometrically corrected LANDSAT products were purchased from the "USGS Earth Explorer" portal. However, the image from CBERS 4 PAN 10, was not previously corrected at the time of acquisition, so geo-referencing was required.

The CBERS 4 satellite image was georeferenced with the QGIS software, followed by an adjustment of the R2G4B3 color composition to enhance the morphological aspects of the channel. The 225/72 image of LANDSAT TM 5 was enhanced and viewed in a R5G4B3 color composition. The same procedure was executed for the 225/72 LANDSAT 8 image, with a R6G5B4 color composition. The vector data containing the boundaries of the present river basin and its drainage network were supplied by company Tractebel Energia. The statistical flow data from the monitoring station $66490000\left(17^{\circ} 36^{\prime} 39.24\right.$ "S $54^{\circ} 49^{\prime} 57.84^{\prime \prime}$ ) were purchased from the portal" Hidroweb "of the National Water Agency (ANA) and processed in Microsoft Excel.

With this information, a geographic database was developed with the creation of new vectors, thus identifying previously uncharted flow paths and mapping stretches of the Correntes River and its basin where significant modifications occurred.

\section{RESULTS AND DISCUSSION}

The lower reach of the Correntes River, located between its entrance to the Pantanal plain and its mouth in the Piquiri River, is approximately $41 \mathrm{~km}$ long. It is characterized by a topographic gradient of only $0.12 \mathrm{~m} / \mathrm{km}$, in contrast to the average gradient of $2.26 \mathrm{~m} / \mathrm{km}$ identified on the plateau (Figure 4). Consequently, the sinuosity in this section is high with an index of 2.12, which characterizes the river as meandering.

Comparing with the dynamics on the plateau, lateral and downstream migration processes developed rapidly and gave the fluvial plain new geomorphic forms. Thus, meandering river features such as abandoned meanders that refer to a past stage of fluvial plain development are recognizable. These features are an evidence of the river morphology and reflect the channel dynamics. The identification of abandoned meanders and the processes that formed them provides information to anticipate new changes to guide land-use planning, thereby avoiding inappropriate land use near the channels.

From the hydrological point of view, the installation of the Ponte de Pedra HPP influences the fluvial channel upstream and downstream of the dam. Coelho (2008) found that upstream impoundment impacts can be perceived by sediment deposition, stream velocity reduction and water level rise. Storage of solid and liquid load, sedimentation with consequent reduction of the useful life from the dam, and increased infiltration rate with greater groundwater availability affect the reservoir. Downstream the dam, the largest impacts, due to the regulated river discharge, are reduction of solid load, change to infiltration rates and, consequently, increase of groundwater, among others. 
Silva, E. R. dos S. da / Silva, A. /

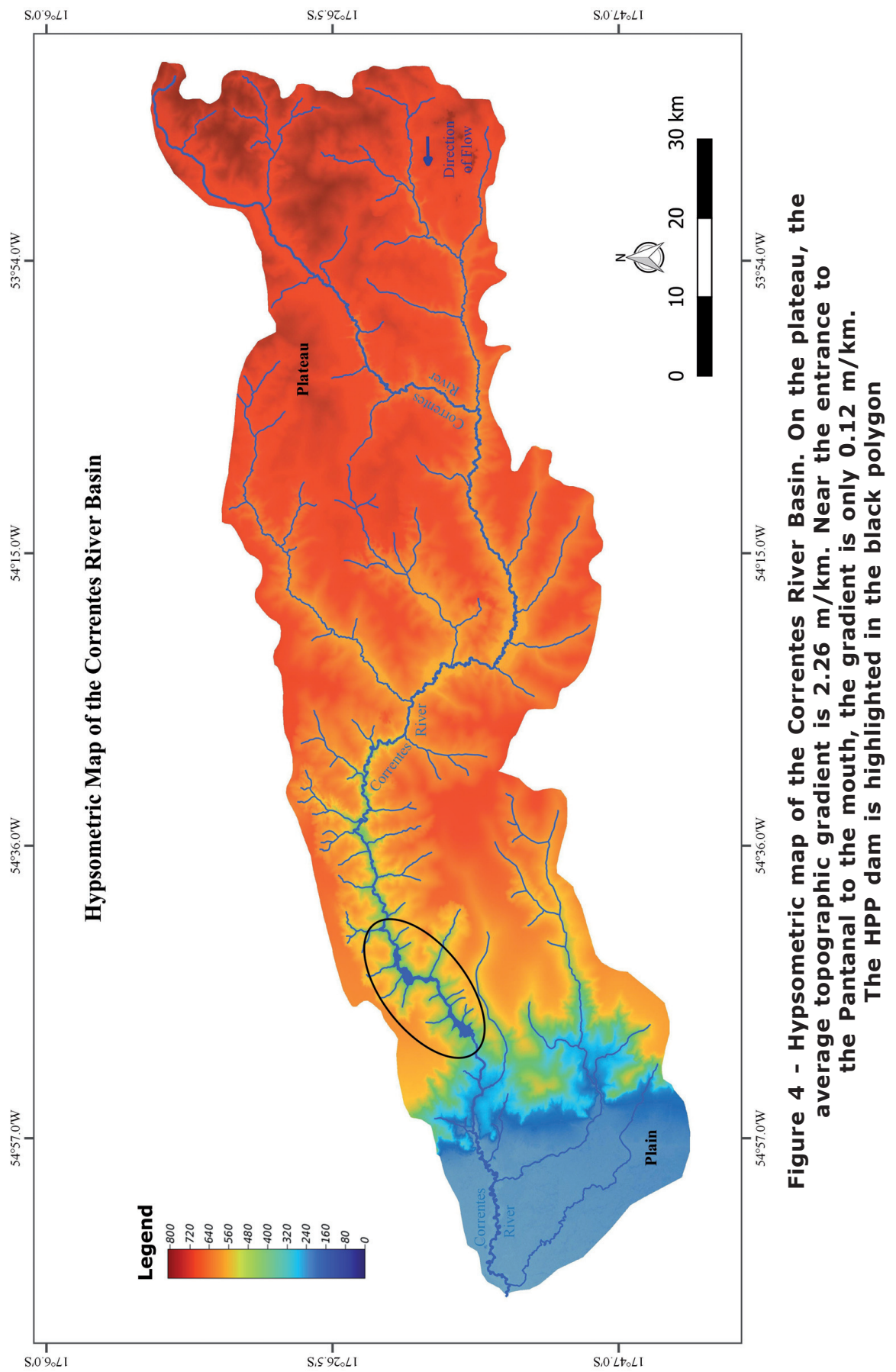


As for the Correntes River, it is not yet possible to identify the hydrological impacts of the Ponte de Pedra HPP installations due to insufficient flow data in the channel that pours into the Pantanal plain. However, data acquired from ANA at the monitoring station 66490000 (170 36'39.24"S 5449'57.84"W) shows the great water flow variation that has occurred following the dam installation (Figure 5). This monitoring station is located in the channel section of $\sim 12.7 \mathrm{~km}$ length where water flow is exclusively released by the Ponte de Pedra HPP spillway (flow of $\geq 9.7 \mathrm{~m}^{3} / \mathrm{s}$ ).

The Ponte de Pedra HPP began operations in September 2005. Including this period, the historical average flow is $83.03 \mathrm{~m}^{3} / \mathrm{s}$. Before the installation of the dam, the maximum peaks were $>127 \mathrm{~m}^{3} / \mathrm{s}$ and the minimum $\leq 48 \mathrm{~m}^{3} / \mathrm{s}$. However, since the HPP became operational, the flow of this section has changed drastically, with maximum peaks $<60 \mathrm{~m}^{3} / \mathrm{s}$ and minimum $\leq 12 \mathrm{~m}^{3} / \mathrm{s}$. Unfortunately the flow data from the monitoring station 66490000 are limited to 2006 and incomplete with discontinuities throughout the recorded period.

The maximum daily flow registered in $2006\left(52.99 \mathrm{~m}^{3} / \mathrm{s}\right)$ in the year after the HPP started operations, is significantly lower than the daily minimum flow rate recorded in $2003\left(76.76 \mathrm{~m}^{3} / \mathrm{s}\right)$, i.e. in the year before dam construction. Another important factor is the regulated river discharge. In 2003, the flow variation relative to the annual average was higher, while in 2006 the flow variation was lower and remained closer to the annual average (Figure 6).

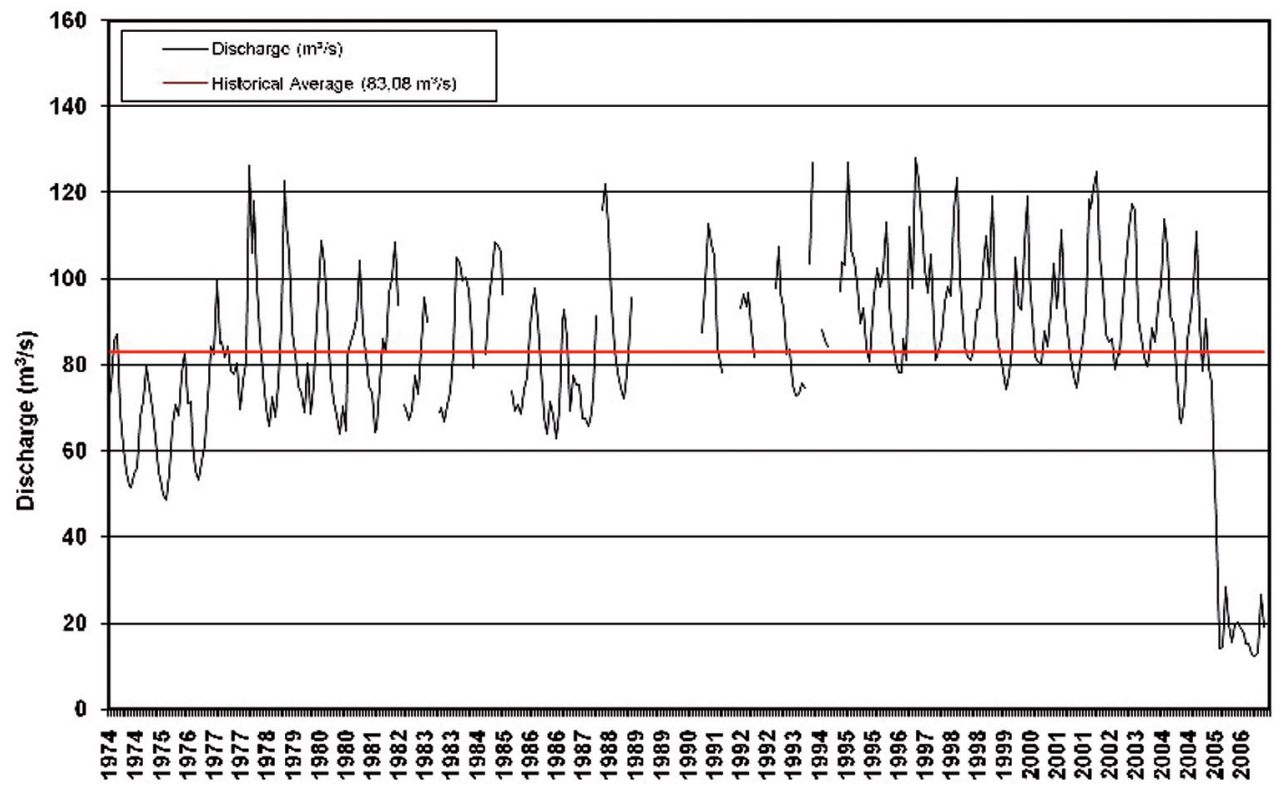

Figure 5 - Average monthly flow varies between 1974 and 2006. After the HPP installation and operation, the flow of the section was drastically altered. Monitoring station 66490000

Source: ANA, 2016.

Although the average monthly flow approached the average annual flow in 2006, some periods showed greater amplitude with values exceeding regulated limits. 
In March 2006, the maximum flow rate of $52.99 \mathrm{~m}^{3} / \mathrm{s}$ was recorded in day 30 , whereas the minimum for the same month was only $14.46 \mathrm{~m}^{3} / \mathrm{s}$, observed on day 4 . Similarly, the maximum flow was recorded on day $11\left(48.62 \mathrm{~m}^{3} / \mathrm{s}\right)$, whereas the minimum was recorded on day $24\left(12.44 \mathrm{~m}^{3} / \mathrm{s}\right)$, with a monthly average of only $26.72 \mathrm{~m}^{3} / \mathrm{s}$ in November.

For the average monthly stage before the installation of the HPP, the values remained near or above the historical average discharge for the period $\left(102.09 \mathrm{~m}^{3}\right.$ / s). However, after the hydroelectric dam began operations, the river stage dropped to a minimum of only $19 \mathrm{~cm}$. Similar to the flow in 2006, the amplitude increased between the maximum and minimum stage values. Between February, March and April 2008, stage values $>80 \mathrm{~cm}$ were recorded, while in November, a mean value of $26 \mathrm{~cm}$ was recorded (Figure 7 ).

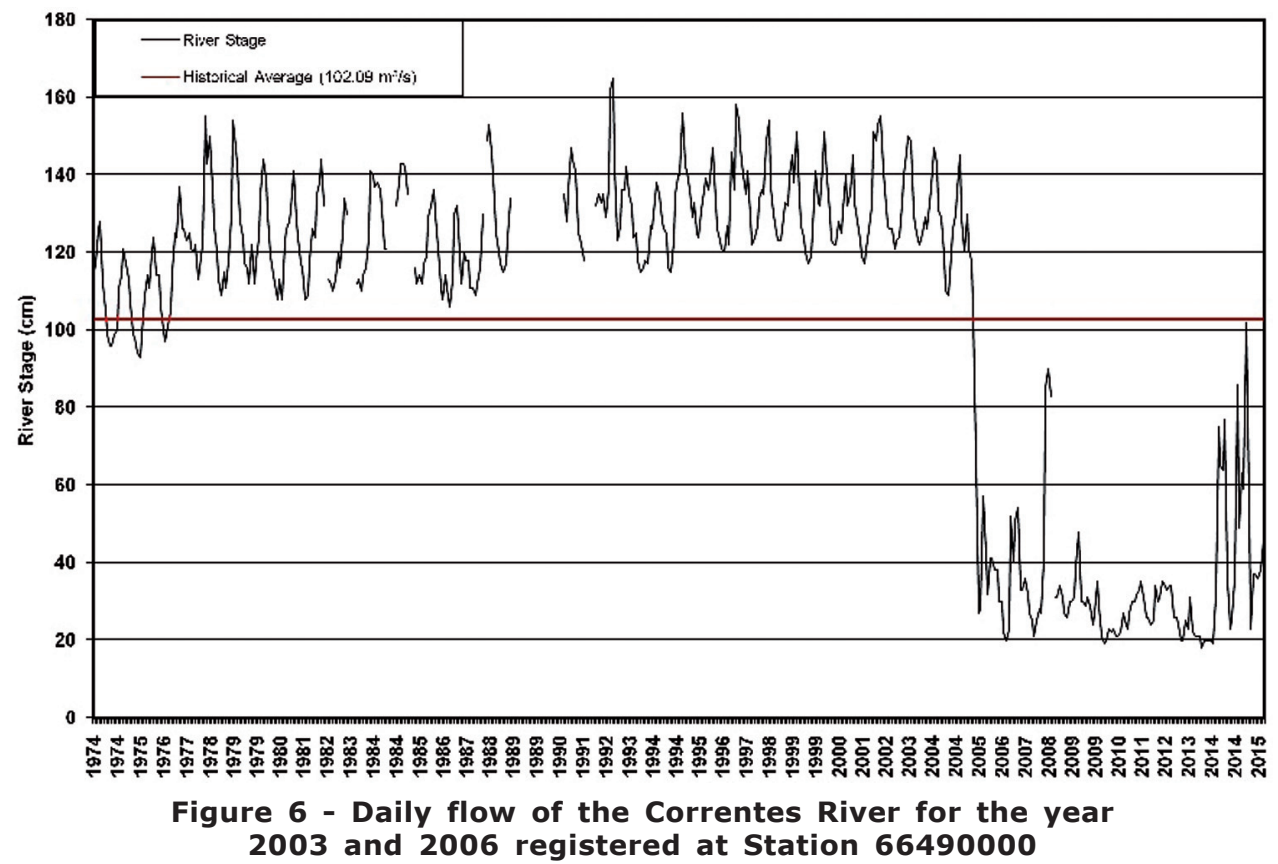

Source: ANA, 2016.

These variations in fluvial discharge in the natural channel from the Correntes River are directly related to the floodgates releases to the HPP spillways. They can indicate periods during a larger river discharge when the water volume is close to the safety limit and emergency procedures are conducted for the reservoir and its surroundings. The variations can also signal a drop in the volume of water discharged and the need for greater impoundment to maintain a sustainable volume of water to generate energy.

The recognition and comparison of the morphology from the lower Correntes River in 1984 and 2016 helped to identify curves that have changed. In this reach, several meanders are migrating, which indicates the expansion and predominance of erosive processes in the concave margins (Figure 8 ). The relative stability of other 
river curves can be noted on the satellite images through the comparison of vectors from the channel in both periods studied (Figure 9).

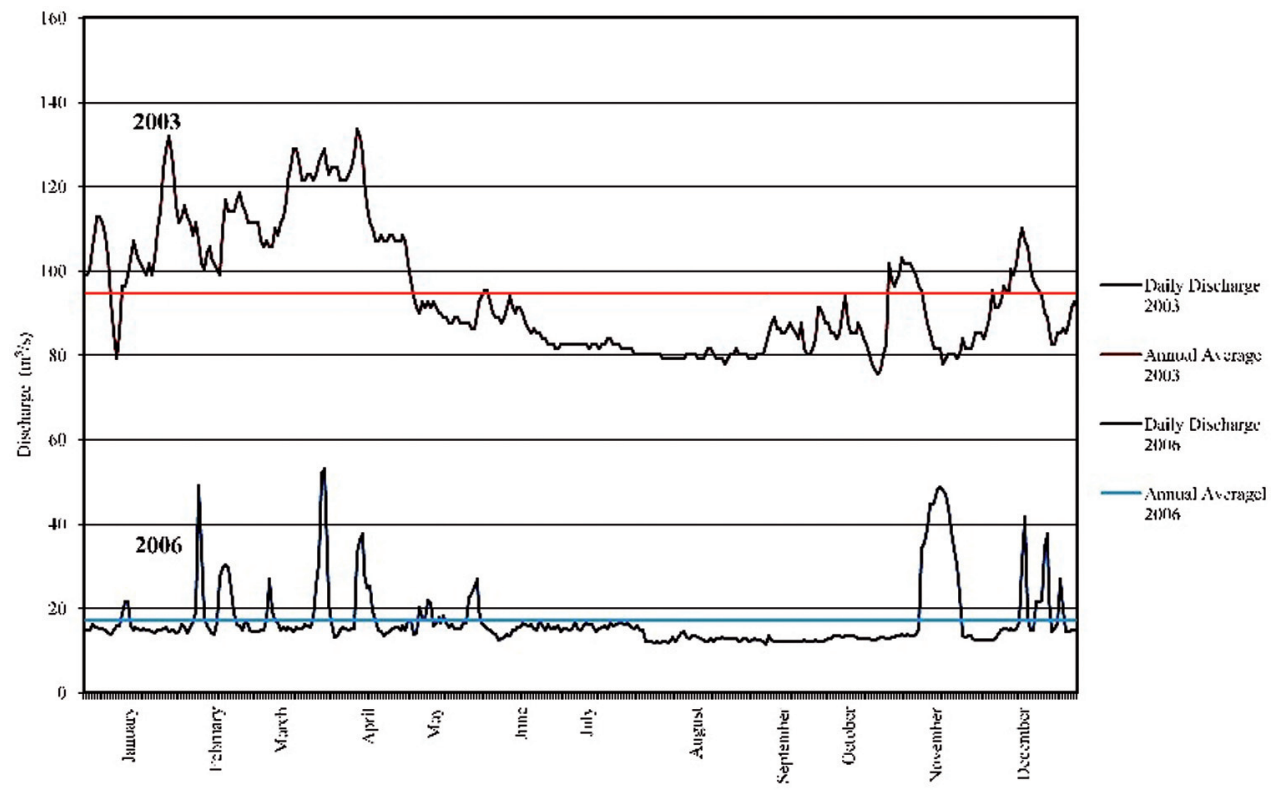

Figure 7 - Variation of the monthly average river stage between 1974 and 2015, with the historical average for the period of $102.09 \mathrm{~m}^{3} / \mathrm{s}$, registered by Station 66490000

Source: ANA, 2016.

The continuous expansion of the meanders can increase or decrease the channel sinuosity. The expansion increases sinuosity by enlarging the curvature radius. In some cases, the expansion of the curves can trigger meander cutoff, with the consequent formation of oxbow lakes and decreased sinuosity. 

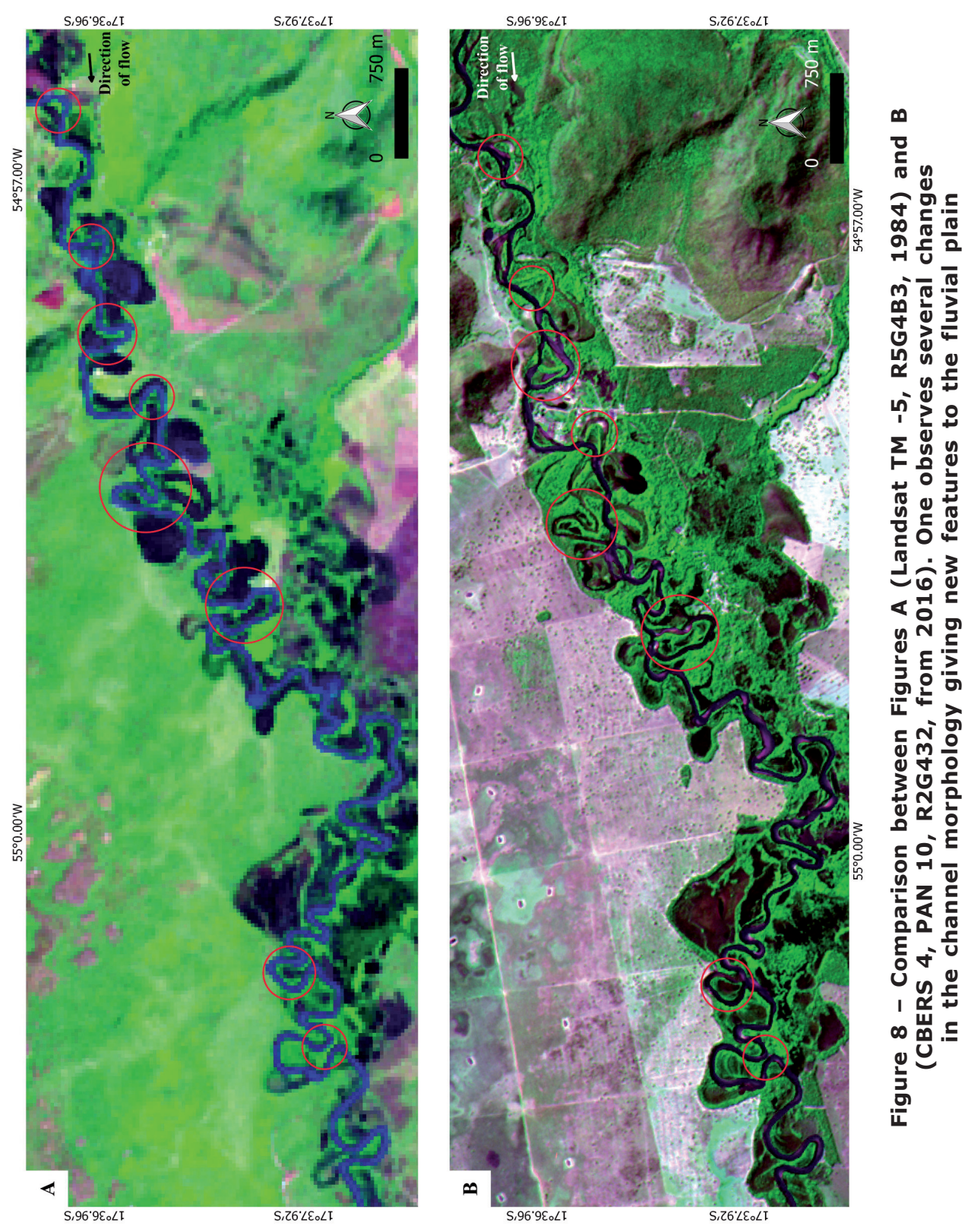


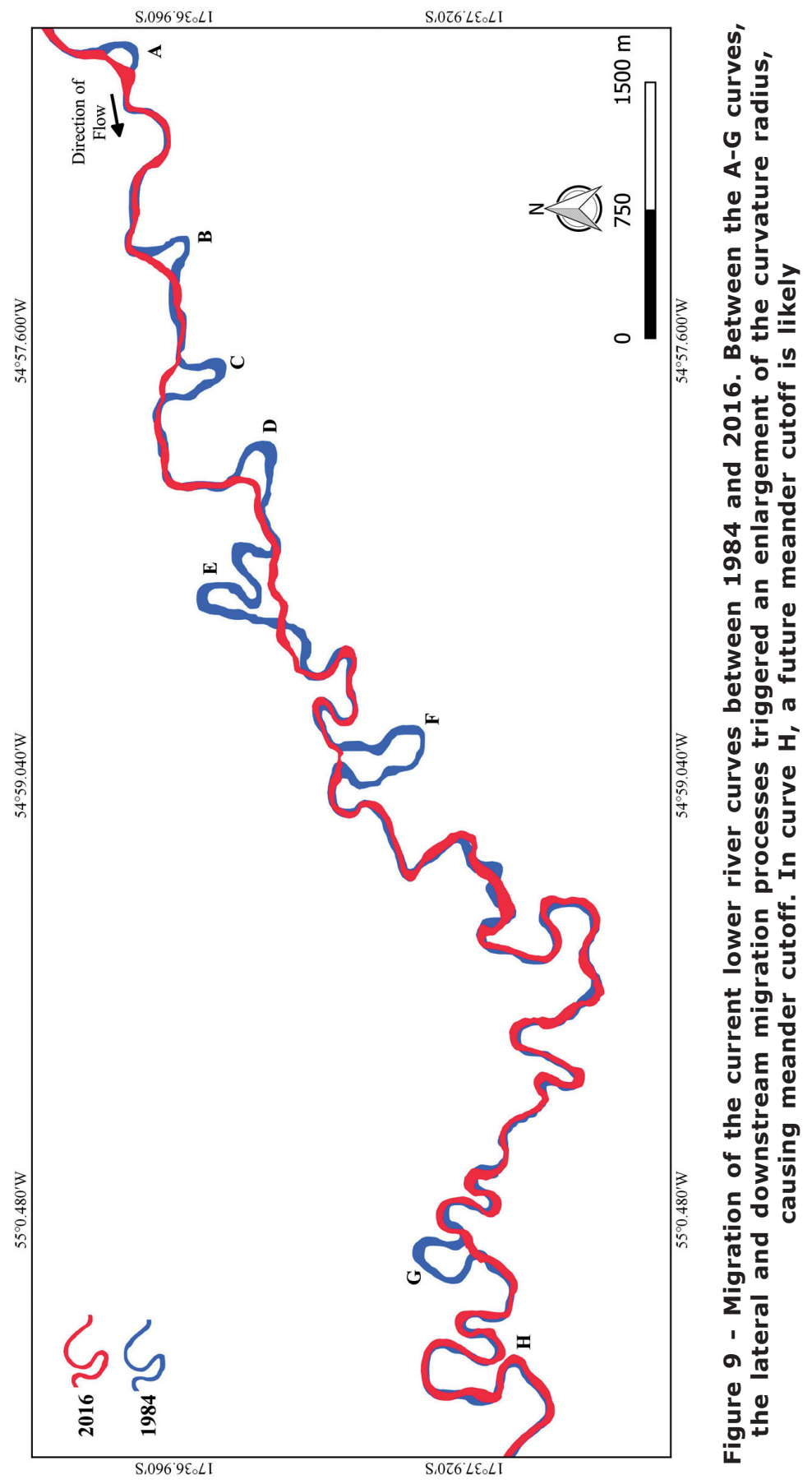


In this sense, Christofoletti (1981) found that the curvature radius of the meanders is inversely related, i.e., the increase in the curvature of a given meander decreases the curvature of the adjacent curve. Thus, while there are significant changes in some curves of the Correntes River, other ones remain relatively stable due to erosion in the concave margins and deposition in the convex margins.

In the 32-year time span analyzed, the Correntes River shows the predominance of accelerated erosion in the concave margins and deposition in the convex margins, leading to the expansion of the curvature of the meanders and, in some cases, to meander cutoff (curves $A, B, C, D, E, F$ and $G$ ). In curve $H$, an increase of the curvature radius will likely cause meander cutoff, further reducing the channel sinuosity. On Figure 10, the featured E D and $\mathrm{F}$ curves show readily observable morphological changes altering the course of the channel and giving the fluvial plain new meander features.
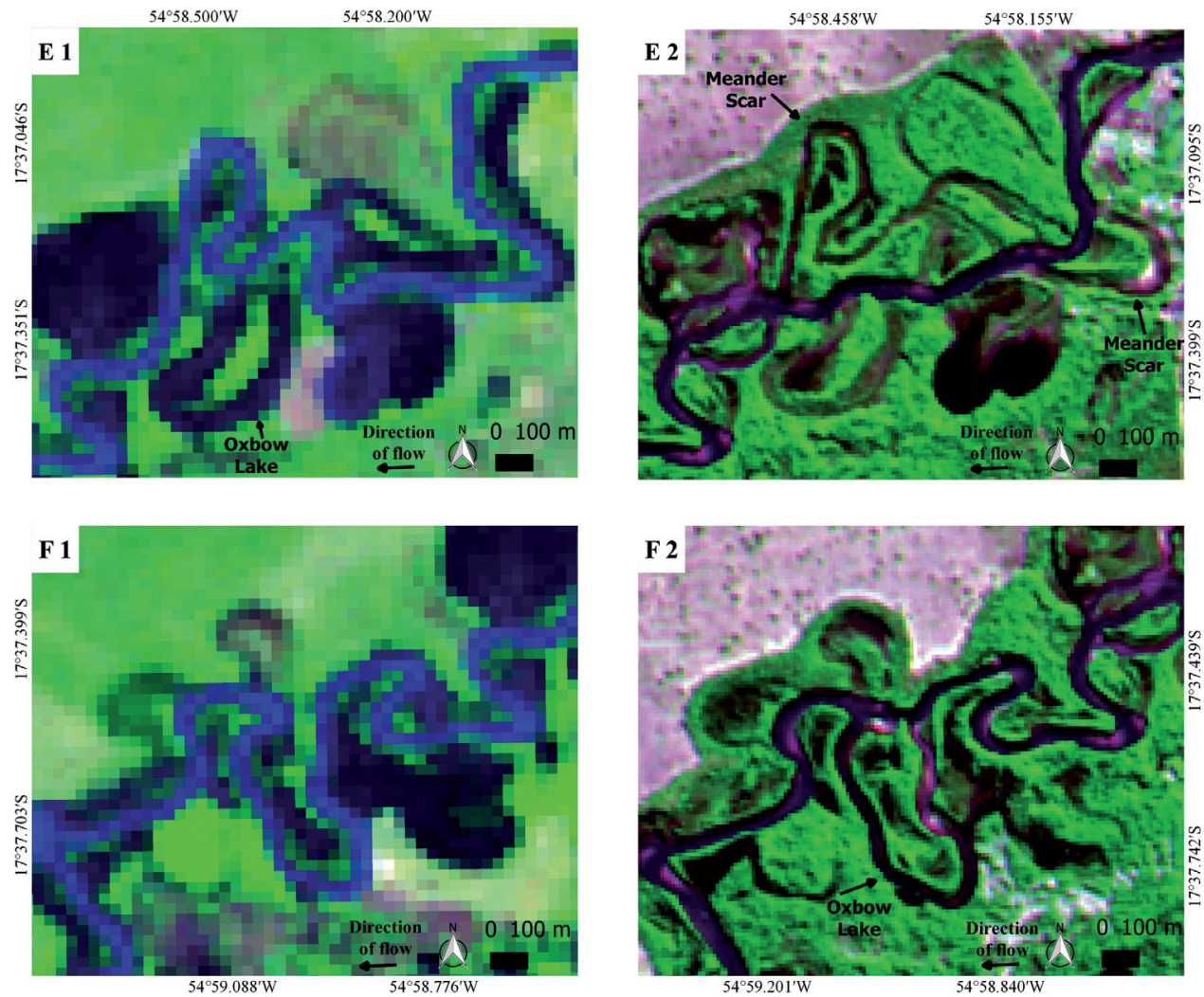

Figure 10 - Changes occurred in the channel of the Correntes River during the analyzed period. In the images, geomorphological forms (abandoned meanders and point bars) can be observed

Source: LANDSAT 5, composition R5G4B3, August 1984. CBERS 4, composition R2G4B3, May 2016.

Comparing the meandering curves, one sees that the sinuosity in the lower Correntes River varied between 1984 and 2016, with indices of 2.28 and 2.12, 
respectively. This tendency reflects the adjustment of the river channel in response to hydro-sedimentary factors. In turn, this adjustment is continuous, but human interventions such as the installation of a hydropower plant can influence many factors, e.g., the sediment transport regime.

Souza Filho (2013) showed that bedload sediments will be retained in all dams, whereas the retention of suspended sediments will depend on several factors, such as reservoir length, residence time, physical-chemical water characteristics, etc. Thus, the sediment load that enters the Pantanal will decrease. Further data is necessary to confirm this hypothesis.

However, with the lack of detrital input due to sediment retention and no changes to other factors determining the water velocity, the current power will increase, causing the channel adjustment, (SOUZA FILHO, 2013). This adjustment occurs by increase of marginal erosion, stimulating the lateral and downstream migration of the meandering curves. The resulting meander cuts and the decrease of the channel sinuosity were registered in the lower Correntes River.

\section{CONCLUSIONS}

Using a variety of media (geo-technologies, literature review, field survey, and hydrological data analysis), changes were identified in the curvature radius of some meandering curves over a 32-year period. The expansion process can increase and/ or decrease particularly the channel sinuosity over geologic time. This process is possible due to the characteristics of meandering rivers and its surroundings, but can be accelerated by anthropic interferences.

The modifications identified in the last 32 years indicate adjustments of the fluvial channel aiming a balance to hydro-sedimentary factors. Due to the natural system of meandering channels, these modifications tend to occur inadvertently over time, leaving marks of this evolution in the fluvial plain. However, human interventions (such as the installation of a hydropower plant) can accelerate these natural processes by changing hydrological and sedimentological factors. However, the current level of information is not sufficient to establish definitive conclusions about the influence of human actions. Future research is planned in the region to study not only the river dynamics, but also land use in the basin and its influence on the fluvial system.

In the Upper Paraguay River Basin there are several hydropower projects which involve the Pantanal, a particular and complex ecosystem. So it is important to conduct further research and identify the influence of SHPs and HPPs on hydrological values and sedimentary load, which may alter the balance of the Pantanal system.

This research contributed to the identification of the dynamics from the Correntes River and its basin, and generated data and guidelines for sustainable land-use planning.

\section{ACKNOWLEDGEMENTS}

The authors acknowledge institutional support from the Federal University of Mato Grosso do Sul-Pantanal; the Foundation for Teaching, Science, and Technology Development in Mato Grosso do Sul-FUNDECT (Grant 083/2016), the National Council 
for Scientific and Technological Development-CNPq (Processes 447402/2014-5 and 448923/2014-9), and a research productivity grant (PQ2) to A. S. (312.386/2014-1).

\section{REFERENCES}

ANA; GEF; PNUMA; OEA. Implementação de práticas de gerenciamento integrado de bacia hidrográfica para o Pantanal e bacia do alto Paraguai: diagnóstico analítico do Pantanal e bacia do alto Paraguai. Relatório Final. Brasília-DF, 2003. Available at: <http://iwlearn.net/iw-projects/583/reports/diagonistic-analysisof-the-basin-spanish>. Access in June $3^{\text {rd }} 2016$.

ANEEL - Agencia Nacional de Energia Elétrica. PCH's do Estado do Mato Grosso: Eixo Disponível. Brasília-DF, 2015. Available at: < http://www2.aneel.gov.br/scg/Doc/ Publicacao_PCH_MT_EixoDisponivel.pdf>. Access in July $1^{\text {st }} 2016$.

ASSINE, M. L.; SILVA. A. Contrasting fluvial styles of the Paraguay River in the northwestern border of the Pantanal wetland, Brazil. Geomorphology, v.113 p.189199, 2009.

CASTRO, W. de S. Migração dos meandros do baixo curso do Rio Claro, Goiás: processos e fatores controladores. Dissertação de Mestrado (Geografia) - UFG, Goiânia, 2015.

CHRISTOFOLETTI, A. Geomorfologia Fluvial. Volume 1. São Paulo: Edgard Blucher Ltda., 1981.

COELHO, A. L. N.; CUNHA, S. B.; SOUZA, C. A. Efeitos na morfologia Fluvial provocados pelo barramento da UHE Santo Antônio no rio Madeira. Revista Geonorte, v.10, n.1, p.18-24, 2014. Available at < http://www.periodicos.ufam.edu.br/index.php/revistageonorte/article/viewFile/1433/1318>. Access in Dec. $13^{\text {th }} 2015$.

COELHO, A. L. N.; Geomorfologia Fluvial de rios impactados por barragens. Caminhos de Geografia, Uberlândia, v.9, n.26, p. 16-32, 2008. Available at: http:// www.seer.ufu.br/index.php/caminhosdegeografia/article/view/15721> Access in Dec. $7^{\text {th }} 2015$.

CORRADINI, F. A. Geomorfologia Fluvial, Mudanças Ambientais e Evolução do Megaleque do Rio São Lourenço, Quaternário do Pantanal Mato-Grossense. Tese de Doutorado (Geociências e Meio Ambiente) - UNESP, Rio Claro-SP, 2011.

DE BOER, D. H. Hierarchies and spatial scale in process geomorphology: a review. Geomorphology, v. 4, p. 303-318, 1992.

FERREIRA, W. T. da S. Mudanças morfológicas do rio Paraguai no trecho compreendido entre a foz do rio Cabaçal e a foz rio Jauru. SIMPÓSIO DE GEOTECNOLOGIAS NO PANTANAL, 4, Bonito, MS, 20-24 de outubro 2012. Anais... Embrapa Informática Agropecuária/INPE, p.561 -568.

GERMANOSKI, D., RITTER, D.F. Tributary response to local base level lowering below a dam Regulated Rivers: Res. Manage. 2, p. 11-24, 1988.

GORDON, Eric; MITTERMEYER, R. K. Effects of dam operation and land use on stream channel morphology and riparian vegetation Geomorphology, Geomorphology. p. 1- 18, 2006.

GRAF, William L. Downstream hydrologic and geomorphic effects of large dams on American rivers, Geomorphology v. 79, p. 336-360, 2006. 
GUERRA, A. J. T.; CUNHA, S. B. da; Geomorfologia: uma atualização de bases e conceitos. $9^{\circ}$ ed. Rio de Janeiro: Bertrand Brasil, 2009.

IBGE - Instituto Brasileiro de Geografia e Estatística. Projeções da população. Rio de Janeiro: IBGE, 2014. Available at: < http://downloads.ibge.gov.br/ downloads_estatisticas.htm>. Access in May 13 2016.

KLEINA, M. Estilos Fluviais do Rio Sagrado (Morretes/PR): Análise Comparativa dos Anos de 2006 e 2011. Monografia (Geografia) - UFPR, Curitiba-PR, 2013.

KUERTEN, S. Evolução Geomorfológica e Mudanças Ambientais no Megaleque do Nabileque, Quaternário do Pantanal Mato-Grossense. Tese de Doutorado (Geociências e Meio Ambiente) - UNESP, Rio Claro-SP, 2010.

LANGBEIN, W. B.; LEOPOLD, L. B. River Meanders: Theory of Minimum Variance. Physiographic And Hydraulic Studies Of Rivers. Washington: 1966. 21p.

LEOPOLD, L. B., and WOLMAN, M. G. River channel patterns: braided, meandering, and straight, U.S. Gov. Printing Office, Washington, 1957.

MACEDO, H de A. Geomorfologia e Hidrossedimentologia da planície do rio Paraguai, da lagoa Vermelha à confluência do rio Miranda, Pantanal MatoGrossense. Dissertação de Mestrado (Geociências e Meio Ambiente) - UNESP, Rio Claro-SP, 2013.

MACEDO, H de A. Mudanças Paleo-Hidrológicas na Planície do Rio Paraguai, Quaternário do Pantanal. Revista Brasileira de Geomorfologia, São Paulo, v.15, n.1, p.75-85, 2014.

MELO, M. S. de; GUiMARÃES, G. B.; PONTES, H. S.; MASSUQUeTO, L. L.; PIGURIM, I.; BAGATIM, H. Q.; GIANNINI, P. C. F. Carste em rochas não-carbonáticas: o exemplo dos arenitos da Formação Furnas, Campos Gerais do Paraná/Brasil e as implicações para a região. Espeleo-Tema, Campinas-SP, v.22, n.1. 2011. Available at: <http:// www.sbe.com.br/espeleo-tema/espeleo-tema_v22_n1_081-097.pdf>. Access in June $15^{\text {th }} 2016$.

MENDES, N. A. S. As usinas hidrelétricas e seus impactos: os aspectos socioambientais e econômicos do Reassentamento Rural de Rosana - Euclides da Cunha Paulista. Dissertação de Mestrado (Geografia) - UNESP, Presidente Prudente, 2005.

MIRANDA, L. E. A review of guidance and criteria for managing reservoirs and associated riverine environments to benefit fish and fisheries. In: G. MARMULLA, editor. Dams, fish and fisheries: opportunities, challenges and conflict resolution. Rome, Italy: FAO Fisheries Technical Paper, p. 93-141, 2001.

MORAIS, E. S. de; ROCHA, P. C. Formas e Processos Fluviais Associados ao Padrão de Canal Meandrante: O Baixo Rio do Peixe, SP. Revista Brasileira de Geomorfologia, (Online), São Paulo, v.17, n.3, p.431-449, 2016.

MORAIS, R. P. de. Mudanças históricas na morfologia do canal do Rio Araguaia no trecho entre a cidade de Barra do Garças (MT) e a foz do Rio Cristalino na Ilha do Bananal no período entre as décadas de 60 e 90 . Dissertação de Mestrado (Geografia) - UFG, Goiânia, 2002.

PETTS, Geoffrey E.; GURNELL, Angela M. Dams and geomorphology: research progress and future directions Geomorphology, v 71, p. 27-47, 2005.

PUPIM, F. do N. Geomorfologia e Paleo-Hidrologia dos Megaleques dos Rios Cuiabá e São Lourenço, Quaternário da Bacia do Pantanal. Tese de Doutorado (Geociências e Meio Ambiente) - UNESP, Rio Claro-SP, 2014. 
SEMA - Secretaria de Estado de Meio Ambiente e Recursos Hídricos. Relatório de Qualidade das Águas Superficiais da Bacia do Alto Paraguai/MS 2004. Campo Grande-MS, 2005. Available at: < http://www.servicos.ms.gov.br/imasuldownloads/ relatorios/2004/relatorio2004.pdf>. Access in July $1^{\text {st }} 2016$.

SILVA, A. Geomorfologia do megaleque do rio Paraguai, Quaternário do Pantanal Mato-Grossense, Centro-Oeste do Brasil. Tese de Doutorado (Geociências e Meio Ambiente) - UNESP, Rio Claro-SP, 2010.

SILVA, A. Padrões de Canal do Rio Paraguai na Região de Cáceres - MT. Dissertação de Mestrado (Geografia) - UEM, Maringá, 2006.

SOUZA FILHO, E. E. S.; As barragens na bacia do rio Paraguai e a possível influência sobre a descarga fluvial e o transporte de sedimentos. Boletim de Geografia, Maringá, v. 31, n. 1, p. 117-133, 2013. Available at: < http://periodicos.uem.br/ojs/ index.php/BolGeogr/article/view/13638>. Access in July $1^{\text {st }} 2016$.

WILLIAMS, G. P., Wolman, M.G. Downstream Effects Of Dams On Alluvial Rivers. Geological Survey, Professional Paper 1286 U.S. Government Printing Office, Washington, DC, 1984. 83 P. 